\title{
BALTHASAR, Prince of Loam:
}

\section{Pale Fire's Dark Savior - Mechanical Toy or Mystical Man?}

Archetype, Alchemy, \& Allegory: The Jungian Substrate of Nabokov's PALE FIRE, Part III

The child John Shade falls into transcendental unconsciousness at the sight of a wind-up tin toy, a Negro boy pushing a wheelbarrow. Charles Kinbote's Negro gardener trundling his wheelbarrow is the last thing Professor John Shade sees as he completes his poem, just before his unsuspected death. Shade's neighbor Kinbote, upon seeing the mechanical toy Shade kept as a "memento mori" declares that it shall work again because "I have the key" (C 107). What is the key to this mysterious transcendental object, and how is it that Kinbote possess it? What does it mean for it to work again? Why is it a gardener with a wheelbarrow, and why a Negro? And how does the mechanical toy relate to the living gardener?

Nabokov's most recondite and provocative novel, Pale Fire has multiple intersecting and spiraling themes, levels, allusions, and cleverly hidden clues and feints. Nabokov has told us, via John Shade's fountain/mountain epiphany, that there is a 'web of sense' in the novel's elaborate texture (P 810, p.50). In this paper ${ }^{1}$ I will go to the 'underside' of the weave and pick up a number of thematic threads that intersect and converge into the elaborate design of the mechanical toy/gardener dyad. I suggest that the answers to the above questions and their import to an overarching theme, may be found following thematic threads:

\section{Themes and Threads:}

\footnotetext{
${ }^{1}$ This paper is Part III of "Archetype, Alchemy, \& Allegory: The Jungian Substrate of Nabokov's PALE FIRE'. A prior reading of Part I "The Tri-Part Man" and Part II "Sybil: Spider at the Center of PALE FIRE's Web of Sense" lay out more extensively the theory of Jungian archetypes and the separate fictive planes of the "thetic spirals."
} 
(1.) Thetic Spirals and Dual Solutions

(2.) Mysticism

(3.) Autobiography and Auto-Plagiarism

(4.) Alchemy and Opposites

(5.) Death and Resurrection

(6.) Occult

(7.) Symbols and Multiple Meanings

(8.) Psychology: Jungian Archetypes and Parody

\section{Thetic Spirals and Dual Solutions:}

Nabokov claimed that he liked to compose in Hegelian thetic spirals - thesis, antithesis and synthesis. On a spiral, each point along the curve is an iteration of the turn below it, only at a higher, expanded level, and this is what we'll find as the thetic text/plot level spirals to the antithetic hypertextual level, and then to a further expansion as the antithetic moves to the synthetic. The straightforward text/plot level ('text' rather than 'texture') is the thetic level and can be understood - and be satisfyingly complete — on that level. With a full turn of the spiral, the antithetic level uses the same text as the thetic but requires the "texture" of allusions, tropes, themes, etc. to create an analogue, but expanded and more sophisticated, literary experience, one which necessarily involves the reader's engagement. Ultimately, multiple antithetic clues ratchet up the spiral into a meaningful synthesis of 'poignant artistic delight.' (SM, 291-292)

The thetic level belies John Shade's words, 'There are rules in chess problems: interdiction of dual solutions...' (C549, p.174) The 'game' Nabokov set for Pale Fire would seem to be how to break this rule, as he enjoyed doing in composing 'fairy chess,' eschewing the fairly simple 
thetic solution for the roundabout antithetic route. Shade's 'fits' provide an example of how Pale Fire can be read on different thetic levels, resulting in dual solutions. Nabokov does not offer any definitive conclusions as to whether the 'fits' are some sort of medical aberration or an accidental tumble into the cosmic void. He slyly gives clues to both interpretations. The 'medical' view is the doctor's conclusion of heart attack or stroke. The 'mystical' is Shade's own insistence on the 'quiddity' of his transcendental experiences.

I would place the medical view on the thetic level of the plot, not requiring much interpretation beyond what the text presents. Also on the thetic level, is the view, advanced by some, that Shade's most recent 'fit' might have triggered a split of his personality into the alterego Kinbote/King Charles. This is still a medical diagnosis and only explains what happens on the exoteric thetic plot level. Similarly, one need not go hors texte to deduce the abundant clues that Kinbote is delusional and his name a near anagram of 'Botkin,' the real being behind both Shade and Kinbote, yet there is no real proof on the thetic level. The thetic plot level offers no larger view, or connection to the many literary or esoteric motifs of the novel, and nothing to explain why the tin toy had such an effect on young John Shade, or how that relates to Kinbote's gardener, or indeed what precipitated Botkin's psychic split. One critic, Carolyn Kunin, goes to the antithetic level to offer a fascinating and convincing allegory of a 'medical' solution of stroke $^{2}$. According to her, the description of Kinbote's escape from his Zemblan prison/castle capitulates the path of a stroke through the brain. While this ingenious interpretation floats well above the level of the plot, it does not connect back to Shade's precipitating childhood experience of the wind-up toy, nor does it come to any larger thematic conclusions. The number of times the word "stroke" appears in the novel is convincingly purposeful, but I believe the stroke/escape

\footnotetext{
${ }^{2}$ thenabokovian.org, L-Post 0013126, 139160.
} 
analogy is one of Nabokov's intentional 'illusory pattern[s] of play' (SM, 291) and only leads back to the thetic plot level.

On the esoteric antithetic level, we shall see as we proceed through the thematic threads, Shade's fits relate both to the toy and to the gardener. The intersecting antithetic themes lead to a synthetic understanding of the novel, which contains and explicates both the thetic and antithetic levels' by encompassing them in a larger unifying theme. This overarching theme I am calling "transcendence."

\section{Mysticism \& Transcendence}

Deep teleologic and ontological currents of mysticism runs through Nabokov's work, much more than he is generally credited with. There has been some discussion of Gnosticism and NeoPlatonism in his work-Vladimir Alexandrov ${ }^{3}$ covers this especially admirably. However these labels pertain to particular religious movements and belief systems. Nabokov made it clear that he did not participate in any kind of group organization. I prefer 'mysticism' as this term denotes a universal and often spontaneous, ineffable, unifying and individual experience, not requiring explication beyond the quiddity of the experience itself. Individual genius, so important to Nabokov, his anathema of cliché, '-ologies' and '-isms' that generalize, kill and embalm the mystical, and his penchant for parody has kept these themes hidden on the abstruse antithetic and synthetic levels. Also, Gnosticism is considered dualistic; Nabokov never claimed to be a Gnostic, but did pronounce himself 'an indivisible monist' (SO, 124).

\footnotetext{
${ }^{3}$ Alexandrov, Vladimir. Nabokov's Otherworld. Princeton: Princeton UP, 1991.
} 
This is not to say that he did not use Gnostic ideas as metaphors. Nabokov has hinted a number of times in his discursive writing that he had personal experiences of mystical union - famously his: 'I know more than I can express in words, and the little I can express would not have been expressed, had I not known more.' $(\mathrm{SO}, 45) \mathrm{He}$ is in no way being coy here; clearly he understands the ineffability and preciousness of the personal experience of unity. This suggests to me that his understanding is monist, but his efforts to convey this are necessarily dualist-whether as parody, or to remain ambivalent, or because of the basic ineffableness of the experience. The mysticism in Pale Fire does have a Gnostic flavor, but is more inclined towards the Hermetic sorcery of alchemy and its allied occult arts. Unlike Gnosticism, alchemy did not abjure the material world. The artifex believed that his personal efforts could bring divine spirit into matter (including primarily, of course, himself); he becomes himself like a demi-urge. I believe alchemy suited Nabokov's purpose of conveying the artist/author as creator of worlds - just as the Gnostic 'demi-urge' created the material world. The true artist, likewise, through combinational magic 'spiritualizes' matter. I discuss this more later.

Nabokov is never didactic about his mystical ideas and allows for ambiguity and alternate readings, depending on the reader's level of consciousness and engagement. For example, Invitation to a Beheading, Bend Sinister, Tyrant's Destroyed and Ultima Thule all treat the themes of insanity versus enlightenment as dual solutions. Pale Fire addresses this ambiguity more fully but at the same time more covertly. Additionally, Pale Fire is packed with allusions to mysticism and hidden occult images -'bunny eggs' to be discovered by eager 'ultra sophisticated' solvers. The 'bunny eggs' allusion to Easter is not accidental; it is illustrative of the theme of death and resurrection first intimated in Kinbote's amusing coinage $(\mathrm{C}, 66)$. (The allusion to Easter will be taken up in the novel again in reference to Balthasar.) 
John Shade, as his poem reveals, is overtly on a teleological path - searching for meaning in the finite life between the two infinite abysses. Typically, Nabokov keeps the question open as to whether Shade succeeds in the end. Does he die needlessly and ironically on the mundane thetic level, or does he go on to experience a 'hereafter,' as the mystical antithetic level suggests? The same question can be asked of Kinbote's suicide, and even begs the question of the posthumous future of Jack Grey. (I will explore this important question further into the paper).

Another word for the mystical experience is 'transcendence,' which I feel better suits the overarching theme of Pale Fire, as it encompasses several meanings in the work: transcendence of life after death, transcendence of ego-self, and ultimately the transcendence of Art.

\section{Autobiography \& Autoplagiarism}

Young John Shade's 'fits' bear a striking resemblance to the scarlet fever episode of young Vladimir Nabokov (SM, 36-37). For a child, tracing numbers into infinity during an illness delirium was a terrifying expansion into the loss of ego-self; an experience of such force and significance that Nabokov returned to it a number of times. For example, from Pale Fire's antecedent, Ultima Thule, the mystic, Falter says:

'- that the recoil upon perceiving Truth, the instant reaction of one's whole being, remains an unfamiliar, little-studied phenomenon. Oh, well sometimes in children - when a boy wakes up or regains his senses after a bout with scarlet fever and there is an electric discharge of reality, relative reality, no doubt, for you, humans, possess no other.' (TSVN, 510).

Thus, Truth on the 'mystical' level is something that Nabokov and his characters experience, especially in childhood, and especially during sleep or illness - in other words, freed from the rational egoic mind. Another ontological trope, based on a memory from childhood, recurs in Nabokov's fictions: objects rolling out of sight. In Speak Memory, Nabokov relates that 
while traveling by train as a boy he would put himself to sleep imagining that he was the conductor in full control of the train. As soon as he began to lose consciousness he would see '[...] a glass marble rolling under a grand piano or a toy engine lying on its side with its wheels still working gamely.' (SM, 145) This disturbing childhood experience of the loss of control of ego-consciousness apparently followed Nabokov into his adult insomnia. Similarly, in Invitation to a Beheading, a child's ball rolls into and out of Cincinnatus's cell before his epiphany of transcendent consciousness, (or, if you will, insanity). In the short story, Easter Rain (TSVN, 648) a woman in a pneumonia delirium sees a ball of yarn roll under a dresser. As her fever breaks she wakes up to find her nurse on the floor retrieving the ball. Like the ball, she was gone and now she is miraculously back. She breaks into 'peals of laughter [...] feeling that she was resurrected, that she had returned from faraway mists of happiness, wonder and Easter splendor.' (Note again the reference to 'Easter'). The common theme is of an object rolling out of control that leads to an epiphany intuiting Being vs. Nothingness and further, to a sort of mystical cosmic awareness, an ego-death with a glimpse of resurrection.

John Shade's toy rolled under the bed. We don't know if it rolled out again but the concept is similar enough. I believe the boy's shock of awareness was the apprehension that the wind-up toy boy was mechanical, yet out of control, whereas he, a real boy, was alive with consciousness, with being. What would it mean for him, like his toy, to be "out of control," or to disappear? This mind-blowing experience catapulted young John Shade out of his (mechanical, automatic) ego conscious into a state of mystical awareness. As with young Vladimir's fever experience, young John Shade's epiphany was at once alluring and terrifying, too overwhelming for a child to absorb. With no reference place in "reality," his sanity was threatened with an unspeakableness that left him with both "wonder" and "shame" (Line 166). As an interesting and perhaps relevant 
aside, Carl Jung, whose alchemical theories we will look at next, as a boy aged 11, was subject to a period of daily swoons.

\section{Alchemy and Opposites}

Many literary luminaries mentioned or alluded to in Pale Fire were involved with mysticism, metaphysics and the occult, including Shakespeare, Pushkin, St. Augustine, Joyce, Elliot, a whole host of Romantic poets, and, certainly, the mystical psychologist Carl Jung.

Carl Jung was largely responsible for resurrecting the arcane study of alchemy in the Twentieth Century and reinterpreting the recondite material as a psychological process of transformation and transcendence. (An excellent article on the pervasive images of alchemy in Pale Fire is Lyndy Abraham's Alchemic Pale Fire 4 . Abraham, however fails to mention what I feel is crucial in alchemy, and in Pale Fire - the union of opposites. Here we will be looking primarily at alchemy's coniunctio, 'sacred union' or 'sacred marriage,' involving the role of opposites. Insights from alchemy will also explain why the gardener is a Negro.

Alchemy as a process involved combining, dissolving, and recombining opposing elements and uniting them into the whole of the 'philosopher's stone.' (Compare this to Nabokov's 'combinational' genius creating the entire opus of Pale Fire.) The alchemists' opus was considered a coniunctio of opposites, usually sulphur and salt, referred to as the Sun and Moon, or King and Queen. A third element, usually mercury (Mercurius), was the vivifying, catalytic precipitator and subject and object of the process. This was the 'base' element that was to be purified and 'redeemed.' Lowly Mercurius is reborn in the alembic and redeemed as the 'stone,' the product of the sacred union. One of the many names given to the stone was filius macrocosmi,

\footnotetext{
${ }^{4}$ Abraham, Lindy. Nabokov's Alchemical PALE FIRE, DQR, 20(2), pp.102-119.
} 
the son of the world of matter, brought about not by God but by the artifex's own devoted and meditated efforts. Although the alchemists, normally devout Christians, skirted the issue of whether this was in opposition to Christ (called the filius microcosmi, 'Son of God,') or if the redeemed Mercurius was a brother of Christ, a demiurge, they referred to both the filius macrocosmi and filius microcosmi as servitor (savior).

Jung claimed that Christ was a symbol of the self archetype - the totality of a person rooted in the innermost being. However, the Christian religion in practice abandoned its ancient Gnostic roots of the god-in-man to become an only-God-in-only-one-man - Jesus -and only faith, not works, saved sinful Man in a fallen world. Belief in Christ was never abandoned, but contrary to church doctrine the alchemists' efforts to purify and spiritualize Nature were concomitantly to redeem the darkness in themselves. They believed that a man could of himself discover the secrets of the spirit in Nature, and thus knowledge of himself and the natural world. According to Jung, far from signifying Christ, the alchemists' dark Christ, the stone, complements the common conception of the Christ figure at that time, which was too rarified for human needs, too great a remoteness:

'The lapis is at most a counterpart or analogy of Christ in the physical world. Its symbolism, like that of Mercurius who constitutes its substance, points, psychologically speaking, to the self, as also does the symbolic figure of Christ. In comparison with the purity and unity of the Christ symbol, Mercurius-lapis is ambiguous, dark, paradoxical and thoroughly pagan. It therefore represents a part of the psyche which was certainly not moulded by Christianity and can on no account be expressed by the symbol 'Christ.' On the contrary, as we have seen, in many ways it points to the devil, who is known at times to disguise himself as an angel of light. The lapis formulates an aspect of the self which stands apart, bound to nature and at odds with the Christian spirit. It represents all those things which have been eliminated from the Christian model. But since they possess living reality, they cannot express themselves otherwise than in dark Hermetic symbols. The paradoxical nature of Mercurius reflects an important aspect of the self - the fact namely, that it is essentially a complexio oppositorum, and indeed can be nothing else if it is to represent any kind of totality. Mercurius as deus terrestris has something of that deus absconditus (hidden god) which is an 
essential element of the psychological self, and the self cannot be distinguished from a God-image (except by incontestable and unprovable faith).' (V.13, p.241)

Jung held that the dark Christ/Mercurious/self figure represents a natural supraordinate morality within man,

"...not to be equated outright with the collective moral consciousness, as Freud wanted to do with his superego, but rather with certain psychic conditions which existed in man from the beginning and not acquired by experience." (V. 7, p.260)

Jung believed that the alchemists projected their psychic processes into the alchemic process, thus uniting the opposites within their conscious and unconscious. Confronting subconsciously suppressed elements in the psyche - bringing light to darkness - likewise was the key to psychological wholeness, a process that Jung termed 'individuation.' Wholeness, as an archetypal image, Jung called the 'self.' The self is not the ego-self, but the totality of consciousness - the ego and all the unconscious archetypes, high and low. More than just repressed negative instincts, thoughts and wishes, Jung held that the unconscious was also the source of creativity, passion and innate morality of the archetypal self.

The unconscious is not just evil by nature, it is also the source of the highest good: not only dark but also light, not only bestial, semi human, and demonic but superhuman, spiritual, and, in the classical sense of the word, 'divine.' (Jung, V.9i, 338).

Because the whole self is ultimately transcendent and ineffable and cannot be fully known by the ego-mind, it presents itself to the mind only as symbols of wholeness. Thus, the darkness of the unconscious, symbolized by the alchemists' multifarious images of Mercurius, run from low to high, but the filius macrocosmi, being "redeemed" represents the transcendent totality, beyond Good and Evil.

Since Mercurius is often called filius, his sonship is beyond question. He is therefore like a brother to Christ and a second son of God $[, \ldots]$ he is also the counterpart of the Trinity as a whole in so far as he is conceived to be a chthonic triad. According to this view he would be equal to one half of the Christian Godhead. He is indeed the dark chthonic half, but he is not simply evil as such, 
for he is called "good and evil,' or a 'system of the higher powers in the lower.' He calls to mind that double figure which seems to stand behind both Christ and the devil - that enigmatic Lucifer whose attributes are shared by both. (Jung, V. 12, 222.)

Now, how does this relate to the toy/gardener dyad? The first stage of the alchemical process was called the nigredo (black), suggesting a reason why the gardener is a Negro. The nigredo was a phase of dissolution where the alchemist confronted all that was dark within him. It was a mortifico, a death ( $c f$ Shade's momento mori). Another 'a propos name for the nigredo was 'The Ethiopian' or 'The Moor.' The black Moor of the three Magi present at Christ's birth was named 'Balthasar,' the name that Kinbote dubs his Negro gardener, whom he fantasizes in Moorish garb. The Moor's import is foretold early in Shade's poem through the necromantic Aunt Maud's open poetry book: 'The verse book open at the Index (Moon/Moonrise, Moor, Moral)' (Lines 94-95). These words all relate to alchemy. The Moor is associated alchemically with birth and death (resurrection); the Moon with mystery (also important to alchemy as Luna, salt); the moonrise with nightly resurrection; and the alchemic 'dark Christ,' filius macrocosmi, was considered naturally moral. Later, a poltergeist (Aunt Maud?) iterates this scene, setting Shade's table out on the lawn with a dictionary open at "M." (C, 128)

The gardener is earthy, of the earth, chthonic. He is not dark, though, except for his skin. $\mathrm{He}$ is a positive character, caring for nature and people in need, and has intellectual and spiritual aspirations despite his lowly birth. He 'lays a path' for Kinbote at the Goldsworth house. Kinbote calls him 'awfully nice and pathetic'(C, 222). Why 'pathetic'? Does he suffer? He is impotent (or perhaps just not interested?) and 'talkative - does he have anything earth-shaking to say? Such descriptions are normally attributed to another person - viz. Jesus Christ. Balthasar's sobriquet, 'Prince of Loam' is a chthonic play on 'Prince of Peace.' 
The nigredo was also called the caput corvi, 'raven's head,' or sometimes 'raven's stone.' Darkness, death, the name 'Ravenstein' and the homophonic syllable in $n i$-gred- $o$ all suggest that blackguard of Pale Fire, Jakob Gradus. This surprising link of Gradus to the gardener suggests the Jungian view of the unconscious, what Jung termed the shadow, the dark, rejected, repressed aspects within oneself. Dark, dull, bestial Gradus is clearly emblematic of that archetype. Kinbote describes Gradus as 'mechanical.' One could say that psychologically the unconscious operates mechanically, precisely because there is no conscious awareness. The mechanical toy that precipitated young John Shade's swoon is linked now to the 'mechanical' shadow Gradus, precipitator of the rebellion in Zembla. Zembla, the land of opposites is the unconscious; the rebellion the uprising/rising up of unconscious archetypes into consciousness.

One might rightly wonder how it is, that dark destructive Gradus and beneficent Balthasar are both emblematic of the nigredo. In alchemy, it is the protean figure of Mercurius that is transmuted from the base element to the redeemed 'stone,' a.k.a 'philosophic gold' and numerous other epithets, such as filius macrocosmi. Virtually every phase and quality of alchemy has a representation of a form of Mercurius, and likewise, Jung equates the unconscious archetypes with the forms of Mercurius. Gradus and Balthasar are the base and refined poles of Mercurius in the alchemic process. According to Jung,

'The paradoxical nature of Mercurius reflects an important aspect of the self - the fact, namely, that it is essentially a complexion oppositorum, and indeed can be nothing else if it is to represent any kind of totality. Mercurius as deus terrestris has something of that deus absconditus (hidden god) which is an essential element of the psychological self and the self cannot be distinguished from a God-image (except by incontestable and unprovable faith).' (Jung, V. 13, 241, ) 
The alchemy theme thus reveals the toy/gardener dyad to be opposites, both belonging to the unconscious: base-mechanical-dark-death-destroyer-shadow-Devil-Gradus vs. redeemedlive-light-rebirth-savior-self-dark Christ-Balthasar.

That Gradus and Balthasar have a relationship to each other is evident in Pale Fire's denouement scene of Shade's death. Addressing Balthasar in the commentary, Kinbote writes,

'You and I were the last people who saw John Shade alive, and you admitted afterwards to a strange premonition which made you interrupt your work as you noticed us from the shrubbery walking toward the porch where stood - (Superstitiously I cannot write out the odd dark word you employed.)' $(\mathrm{C}, 223)$

Mercurius? Satan? Devil? - I would say most likely “Devil,” since Balthasar's exclamation should work on the thetic plot level as well, and "That devil!" is an epithet someone might cry out upon recognizing a nefarious person. Balthasar subdues Gradus with a spade to the pate; Good trumping Evil, Kinbote calls Balthasar 'Our savior.' (C, 224) But then, their work being accomplished, Gradus and Balthasar ignore Kinbote; they seem to be on strangely amicable familiar terms later, sharing a glass of water and smoking side by side on the steps like old friends, like bookends - i.e. opposites.

\section{Death and Resurrection:}

Indicative of his Christ-nature, the gardener moves into Kinbote's house just after Easter: 'I am happy to report that soon after Easter my fears disappeared never to return. Into Alphina's or Betty's room another lodger moved, Balthasar, Prince of Loam [...]' (C, 76). We never learn the gardener's name, it is Kinbote who dubs his paronomastic sobriquet.

Kinbote first meets Balthasar while he is tending trees along Shakespeare Avenue (C, 222). The 'Moor' is thus suggestive of Othello, but more importantly, the trees he tends pertain to more 
than Shakespeare; they relate to various occult and macabre themes in the novel: 'jove' and 'thunder-cloven' suggest Mercurius/Odin/Thor and 'knotty-entrailed' wittily suggests Gradus's dyspepsia (which, in turn suggests the alchemic 'vitriol,' a caustic, bubbling phase just prior to transformation). The 'phoenix' is an alchemical symbol of rebirth, rising from the ashes to the liberation of the philosopher's stone. The 'weather-defending line tree' is exactly that; a tree planted along a line against the weather (wind and storms being Mercurius's province accompanying Gradus wherever he goes). Both 'pine' and 'cedar' are woods used for coffins, 'willows' mentioned here and elsewhere in the text symbolize death, the 'midsummer elm' relates to the time period of the novel as well as Shakespeare's play, A Midsummer Night's Dream, and 'mulberry' relates to death in that same play (and, again, Gradus' innards as described in Pale Fire). The 'cypress' is a cemetery tree from Illyria, the modern day name for Arcadia. Trees are Jungian symbols for the individuating self, so we might deduce that the gardener's function on the synthetic spiral is to tend the growth of the individuating person. In his alchemical studies Jung writes of the tree as a symbol of the transformed Mercurius-as-dark Christ (V. 13, p. 251ff).

Pale Fire is saturated with images of and allusions to death. It is John Shade's mournful obsession, Gradus' goal, and Kinbote's longed-for release. Most of the literary works referred to in the novel have death as their subject. Alchemy and Jungian psychology have ego-death as their objective.

\section{Occult References}


Besides alchemy there are also references throughout Pale Fire to alchemy's occult analogs, astrology, numerology, Tarot and cartomancy. In reference to Balthasar, the astrology/astronomy link with Boötes I explain later under the theme heading '(7.) Symbols and Meanings.' As for Tarot, note that 'Balthasar' as the Moorish king attending the birth of Christ was a 'magus.' As such, he links to the Tarot card of that name. The card depicts the magus with an infinity sign over his head. The infinity symbol ties Balthasar to the 'lemniscate' of John Shade's poem and John Shade's concern with the 'infinite abysses' on either side of life. The infinity sign is also a number 8 . It has been noted often, but not understood, that the number 8 occurs with some frequency in Pale Fire. According to A.E. Waite, creator of the eminent Rider/Waite Tarot deck,

'This card signifies the divine motive in man, reflecting God, the will in the liberation of its union with that which is above. It is also the unity of individual being on all planes... With further reference to what I have called the sign of life [the infinity symbol] and its connexion with the number 8 , it may be remembered that Christian Gnosticism speaks of rebirth in Christ as a change "unto the Ogdoad... According to Martinism, 8 is the number of Christ. ${ }^{5}$

The actual sequenced number of the Magus card is '1.' As with the self, the magus likewise symbolizes unity of the individual. The numbers in Tarot all have Numerological significance. Numerology, an allied occult art to alchemy, peppered throughout Pale Fire, was also of interest to both Jung and Nabokov. Cartomancy is also suggested with the gardener's spade, possibly the Ace of spades.

Nabokov frequently used the terms and images "magician" and "conjuror," usually to denote the amazing act of artistic creation, and often in reference to himself Nabokov as the conjuring magus/alchemist/artist/demigod behind the work, the totality image of the (possibly

\footnotetext{
${ }^{5}$ Waite, A.E. The Pictorial Key to the Tarot, London: William Rider \& Son Ltd., 1911.
} 
immortal) self that has been developing through these esoteric themes. If not Nabokov himself, this suggests at least Professor Botkin.

\section{Symbols and Multiple Meanings}

These many meanings and allusions to Balthasar are typical of how Nabokov layered multiple meanings to one adumbration, that is, a symbol. Nabokov claimed to dislike symbols, which is not to say he did not make abundant use of them. What he disapproved of, actually, were "signs," that is, equivalencies. Carl Jung defined a symbol as something that cannot be equated to any one definite thing, which semiotically would be only a "sign." A symbol has multiple convergent meanings, which can only be fully expressed in the symbol: '...[A] symbol signifies something more and other than itself which eludes our present knowledge' (Jung, V.I, par. 817). In the same way, the many multi-layered allusions in Pale Fire have more than one interpretation, but nevertheless coalesce. This is different from 'dual solutions,' which co-exist but lead to separate conclusions. Here are three other interpretations of the Negro gardener that, although different from each other and what I have put forth thus far, can be shown to coalesce as added support to the Balthasar/Christ/Self symbol.

Priscilla Meyer ${ }^{6}$ associates Pushkin's play A Feast During the Plague, as well as Pushkin himself (his Ethiopian ancestry), with the toy/gardener. The play features a Negro driving a cart full of murmuring dead bodies. This image of death and the occult correlates with the dark-Christ, death-redemption theme. Moreover, the allusion to Pushkin crosses connecting threads to the themes of alchemy and death and resurrection: The nigredo (black, mortificio) phase of the alchemic process, referred to as the 'Moor,' or 'The Ethiopian.' The Ethiopian (a.k.a. Mercurius)

\footnotetext{
${ }^{6}$ Meyer, Priscilla. Find What the Sailor Has Hidden, Middletown: Wesleyan University Press, 1986, p. 132.
} 
was said to die, to be resurrected at the end of the process into the fabulous 'stone.' This is the redeemed aspect of the base Mercurius. Carl Jung quotes the alchemist Albertus: 'Behold a wondrous restoration and renewal of the Ethiopian! [...] It is the treasure of treasures [...]' (V.12, p.401)

Typical of Nabokov's piling up of allusions, in addition to the magus there is another 'Balthasar' in the Bible, whose story also fits the gardener: Daniel was a captive of the proud and profligate Babylonian King Belshazzar, who had plundered the treasure of the Israelites. The hand of God wrote an undecipherable message on the palace wall. Daniel, a magus himself, referred to as 'chief of the magicians, enchanters, Chaldeans, and astrologers,' (Daniel 5:11), was asked to interpret the mysterious writing. It was a warning to the King that he had disobeyed God by his ego-centricity. Daniel was rewarded for his prophesy, but the King died that night anyway.

It is not King Belshazzar, however, whose name relates to Balthasar. Under the Babylonians Daniel was given the name "Balat-shar-usr," the etymologic root of Balthasar. The name means literally 'save the life of the king.,

Although Daniel was a Hebrew and not black, we have here again a magus association of Balthasar. We also have a coded warning, the handwriting on the wall, suggesting Pale Fire's cryptic message in the barn. And, we have Balthasar saving the narcissistic thieving King, who dies anyway.

Ljiljana $\mathrm{Cuk}^{8}$ gives a very interesting astronomical interpretation of the mechanical toy, the gardener, and their association to the constellation Boötes She notes that the Great Bear (mentioned in Shade's poem, line 119) is part of the constellation 'Boötes, The Ploughman,'

\footnotetext{
7 (https://www.etymonline.com/search?q=Balthazar)

${ }^{8}$ Cuk, Ljiljana. Shine On, Nabokov, Celestial keys to Pale Fire, Novi Sad: Graphic Studio SPUTNIK, https://drsuttonsite.wordpress.com/dr-sutton-who-or-what/).
} 
being the plough itself, sometimes considered a cart (i.e., a wheelbarrow) and also referred to, interestingly, as 'Charles's Wain.' The myth of Boötes fits the 'mirror image' themes pervading Pale Fire:

The god Philomenus (Boötes The Ploughman) was the twin brother of Plutus, god of the underworld. Philomenus was not rich like his brother but he gave to mankind the plough and the cart. He was rewarded for his generosity and ingenuity by being made a constellation. He is thus associated with the earth, chthonic and dark like his twin, but also with the sky. He has a beneficent aspect; his gifts are material and functional and therefore on the high end of the 'instinct-spiritual' polarity which Jung ascribed to the unconscious. Philomenus and Plutus are opposites: beneficent $v s$. malevolent. They are nevertheless both chthonic, like Balthasar and Gradus.

Boötes the ploughman may also connect with a medieval allegory by William Langland, Piers Plowman. It is a 'Hero's Journey' of Langland's dreams and visions. In a dream of the Tree of Charity he meets a gardener, Piers the Plowman, and has a vision of the life of Christ and the defeat of the Devil. He wakes and goes in search of Christ. Piers is not Christ, but has been "graced by Christ;" he is St. Peter, the founder of the Church. Like Boötes, he is a helper to mankind, earthy but elevated.

Boötes is a near anagram of 'booties,' which Kinbote finds in the closet. Cuk points out the many references to footwear in Pale Fire, including the shoe on the lawn left behind by somnambulist (or astral-traveller) John Shade: his 'secret stamp, the Shade impress' (P, 53). This suggests his innermost being, stamped by the Creator. The name 'Botkin' means 'shoemaker,' suggesting Botkin as Gnostic Demi-urge creator. Who, then, is Pale Fire's demi-urge, or Jungian self-Balthasar or Botkin? In the Jungian paradigm, we could say that Botkin is the real self, 
made up from all of the character archetypes, but Balthasar represents the archetype of the symbol of the real ontological self.

\section{Jungian Archetypes: Parody and Allegory}

The theories of the psychologist Carl Jung have already been threading through this paper. Important as these are for my theory, I have saved this section for last because I did not want to be too front-heavy with Jungian concepts.

We have seen how the gardener Balthasar is implicated in various allusions to mysticism and the occult on the antithetic level of Pale Fire. However, these allusions do not yet explain the role of Balthasar in the novel. To bring together these threads into the meaning and import of this character within the action of the novel, we need to take a closer look at how Jungian motifs form a major substrate to the Pale Fire. Understanding how Nabokov has used Jung's theories of archetypes and alchemy as a parodic sub-structure for Pale Fire, the relationships of the all characters become resolved when viewed as sub-personalities of one person's psyche. This resolution opens up the possibility of the larger theme of transformation and transcendence.

Space does not allow for a full explication of Jung's theories or how each character evinces the Jungian archetypes. Here I must refer to my other papers on the subject for more indepth discussion (MR 1, 2, 3, 4). Briefly, Jung held that psychic wholeness, which he termed individuation, could be achieved through uniting the conscious with the unconscious. Usually people experience their unconscious through archetypes projected outwards onto other people and events, or in bewildering outbursts of psychic eruption. Often it is a traumatic event that forces one to confront these unconscious images in the psyche. Jung felt that how one handles this may lead to either psychosis or the first step on the path of individuation. He believed that by 
retrieving one's projections, through recognition of their source as being within one's psyche, perceived threats can be dismantled and de-potentiated and the consciousness unified.

According to Jung, there are five main archetypes of the psyche: the ego, persona, shadow, anima, and self. Insane and solipsistic Kinbote is the Ego writ large. John Shade, who's 'being constituted a mask,' is the persona, the idealized self-image-Kinbote, as insecure and inflated ego, wants to appropriate his glory. Bestial Gradus, as noted, is the shadow, the repressed unconscious, as are all the other Zemblan Shadows. The anima, the contra-sexual archetype, appears in various guises: Sybil as major antagonistic anima, Disa as neglected soul, Hazel as rejected self-image and Fleur as alluring anima extraordinaire. Jung claimed that the persona was usually the first archetype to confront, then the shadow, but the anima was the main hindrance to realizing the self, the inner true identity. Balthasar, we have already identified as the self.

Kinbote, as ego, is the primary character of Pale Fire. According to Jung, it is the ego that must confront and assimilate the archetypes for individuation. This is why Kinbote has the "key"; as so often happens in myth and fairy tales, the hero discovers eventually that he has always had the key, or special talisman, with him. The key that opened the door to the subterranean tunnel in the Zemblan castle is the key that re-activates the threatening dark maze of the unconscious. Kinbote's attention is brought to the key by a glinting 'spark.' This precipitates Kinbote's 'Hero's Journey' of individuation, allowing in the end for the saving grace of the munificent, higher self. That is why the Negro gardener Balthasar, as emblematic of the ontological self, overcomes the 'mechanical' shadow, Gradus. It is why Kinbote calls the gardener 'our savior.'(C, 224)

One might wonder: Why would Kinbote's key to the tunnel be the key to Shade's toy? Kinbote, when he sees Shade's momento mori, says, '...the rusty clockwork shall work again, for I have the key' $(\mathrm{C}, 107)$. Allegorically, why would the key to Kinbote's unconscious be the key to 
Shade's transcendence (death)? We are about to answer the questions posed at the beginning of this paper: Because this only makes sense if they are actually the same person (as are all the character-archetypes) - Botkin.

Young John Shade (Botkin) witnesses his mechanical toy disappear under the bed. Presumably, the paradox of a mechanical boy vs. his own living being jolts him into an experience of cosmic consciousness. The ecstasy and allure of this inexpressible event was too much for the child, so he shamefully resigns it to his unconscious. On the antithetic allegoric level, Botkin, as a boy, evinces the high qualities of the psyche, including a preternatural mysticism. This is Jung's archetype of the child, that is, of innocence before the ego or persona emerge. The innocence of the divine child is akin to the self. When young Botkin feels shame from his ecstatic experience, denies it and opts for 'normalcy' and conformity, that is the emergence of the persona, Shade. It is not until Botkin/Kinbote (ego) sees the memento mori in Shade's basement (i.e. Botkin's unconscious), along with a handless clock (the unconscious is "timeless") that Kinbote/Botkin realizes that he has the key to resurrect the transcendent experience of the divine self again. Though deeply buried, it has always been with him. Kinbote's first intimation of the presence of the self happens a little earlier, with the introduction of Balthasar into his life. The scene in Shade's basement takes place '[o]ne evening in may or June' $(\mathrm{C}, 106)$. Balthasar moves in with Kinbote just after Easter, the symbol of resurrection. Kinbote immediately feels relief from his angst; 'I am happy to report that soon after Easter my fears disappeared never to return. Into Alphina's or Betty's room another lodger moved, Balthasar, Prince of Loam, as I dubbed him...' (C, 76) The equivalency of the mechanical toy and the ontological self does not become fully manifest until the day that Shade dies and Gradus is dealt a devastating blow. Archetypally, the idealized self-image (persona) is destroyed when 
faced with the rejected shadow, and the light (Balthasar) overcomes the dark (Gradus). This is not yet the end of the journey for Botkin/Kinbote. In the Jungian paradigm, confronting the anima is final feat for individuation. The surprising outcome of the confrontation with Sybil I treat in my paper, 'Sybil: Black Widow Spider at the Center of PALE FIRE's Web of Sense.'

Again, the self is not the ego-self, but a symbol-producing archetype of totality and wholeness within the mind. The goal of Jungian individuation is for the ego to become increasingly aware of aspects of the self. The self includes the conscious, unconscious and superconscious, and is ultimately transcendent to all. The self itself is unknowable in its totality, but can be apprehended through symbols of totality, such as the uroboros mandala, or a divine personage, such as Christ, or in the alembic as the 'stone.' Jung saw the self as equivalent to the end product of the alchemical process - the gold, the stone, the treasure, etc. This inner divinity was considered like a dark brother of Christ - earthy, but spiritual, like the redeemed Mercurius or the Moor. Another epithet of the inner being was the scintilla - 'divine spark.' Although Botkin is the individual whose mind contains these particular character-archetypes, Botkin is not himself identical with Balthasar. Balthasar is a symbol produced within Botkin's mind of his inner self-archetype. The ontological self remains the unknowable, uncontainable, divine spark, the pale fire, as it were, of the blaze of transcendent divinity.

\section{Mary Ross}

San Francisco 


\section{Works Cited}

Vladimir Nabokov, Novels \& Books:

Nabokov, Vladimir. Pale Fire, New York: Everyman's Library, Vintage International, 1992.

---Ada, New York: Vintage International, Random House, 1970 (ADA)

---Bend Sinister, New York: Novels \& Memoirs 1941-51, The Library of America, New York. $(B S)$

---The Stories of Vladimir Nabokov, New York: Vintage International, Division of Random House, Inc., 1997. (TSVN)

---Speak Memory, New York: Vintage International, Division of Random House, Inc., 1989. $(S M)$

Carl Gustav Jung: Collected Works, Vol. 1, Princeton: Bollingen Foundation, Princeton University Press, 1969.

---Jung, $C W$, Vol. 7

---Jung, $C W$, Vol. 9i

---Jung, CW, Vol. 12

---Jung, CW, Vol. 13

Other Works:

Abraham, Lindy. Nabokov's Alchemical PALE FIRE, DQR, 20(2), pp.102-119.

Alexandrov, Vladimir. Nabokov's Otherworld. Princeton: Princeton UP, 1991.

Boyd, Brian. Nabokov's Pale Fire, Princeton: Princeton University Press, 1999. 
Campbell, Joseph. The Hero with a Thousand Faces, Princeton: Princeton/Bollingen Commemorative Edition, 2004.

Meyer, Priscilla. Find What the Sailor Has Hidden, Middletown: Wesleyan University Press, 1986.

Kunin, Carolyn. The Nabokovian Listserve Posts (L139-160), thenabokovian.org.

Waite, A.E. The Pictorial Key to the Tarot, London: William Rider \& Son Ltd., 1911.

Cuk, Ljiljana. Shine On, Nabokov, Celestial keys to Pale Fire, Novi Sad: Graphic Studio SPUTNIK, https://drsuttonsite.wordpress.com/dr-sutton-who-or-what/).

Ross, Mary.

Ross, Mary. Vanessa Atalanta: Butterfly of Doom, The Nabokovian Notes 75, Spring 2018. (MR 1)

--- Kinbote's Hero's Journey: Transcendent Path or Dead End?, (Unpublished) https://independent.academia.edu/MaryRoss22 (MR 2)

--- Sybil: Black Widow Spider at Pale Fire's Center of the Web of Sense, (Unpublished) https://independent.academia.edu/MaryRoss22 (MR 3)

---The Tri-part Man: Alchemy and Archetype in Nabokov's Pale Fire (Unpublished) https://independent.academia.edu/MaryRoss22 (MR 4) 